\title{
Consumer Knowledge Sharing Behavior and Consumer Purchase Behavior: Evidence from E-Commerce and Online Retail in Hungary
}

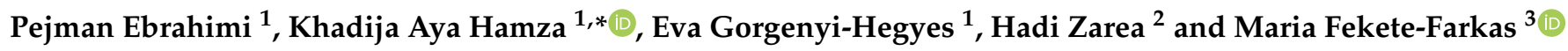 \\ 1 Doctoral School of Economic and Regional Sciences, Hungarian University of Agricultural and Life \\ Sciences (MATE), H-2100 Gödöllő, Hungary; Ebrahimi.Pejman@stud.uni-mate.hu (P.E.); \\ gorgenyieva@gmail.com (E.G.-H.) \\ 2 Faculty of Administrative Sciences, Laval University, Québec, QC G1V 0A6, Canada; hadi.zarea.1@ulaval.ca \\ 3 Institute of Economic Sciences, Hungarian University of Agricultural and Life Sciences (MATE), \\ H-2100 Gödöllő, Hungary; farkasne.fekete.maria@uni-mate.hu \\ * Correspondence: khadija.hamza@yahoo.fr; Tel.: +36-203-345-811
}

check for updates

Citation: Ebrahimi, P.; Hamza, K.A.; Gorgenyi-Hegyes, E.; Zarea, H.; Fekete-Farkas, M. Consumer Knowledge Sharing Behavior and Consumer Purchase Behavior: Evidence from E-Commerce and Online Retail in Hungary. Sustainability 2021, 13, 10375. https:// doi.org/10.3390/su131810375

Academic Editor: Riccardo Testa

Received: 27 July 2021

Accepted: 2 September 2021

Published: 17 September 2021

Publisher's Note: MDPI stays neutral with regard to jurisdictional claims in published maps and institutional affiliations.

Copyright: (C) 2021 by the authors Licensee MDPI, Basel, Switzerland. This article is an open access article distributed under the terms and conditions of the Creative Commons Attribution (CC BY) license (https:// creativecommons.org/licenses/by/ $4.0 /)$.

\begin{abstract}
The twenty-first century has been full of fundamental changes in consumers' behavior patterns, especially with the use of diverse social media knowledge-sharing platforms. Therefore, companies have highlighted the significance of knowledge sharing and the importance of social network use in purchasing processes. Accordingly, his paper tries to reveal how consumer purchase behavior (CPB) can be affected by consumer knowledge sharing behavior (CKSB) and the moderating role played by value co-creation dimensions, which are citizenship behavior (CB) and participation behavior (PB), within a sustainable e-commerce field. To test our hypotheses deducted from the literature review, we opted for the PLS-SEM method. We also employed other innovative approaches, such as the IPMA matrix, MAICOM test, FIMIX approach, and CTA analysis, to evaluate the outer and inner model. Our statistical population covered individuals living in Hungary with at least one online purchase involvement. We distributed the questionnaire via various online platforms and, finally, 433 completed questionnaires were prepared for analysis. The results showed that $\mathrm{CPB}$, $\mathrm{CB}$, and $\mathrm{PB}$ are positively influenced by the CKSB. However, the link between $\mathrm{CPB}$ and $\mathrm{CB}$ was not confirmed. As for the moderating role of gender, the permutation test was applied to compare male and female groups and see the difference between them. With a focus on CKSB, this study contributes to the success of international marketing strategies to attain higher competitive advantages.
\end{abstract}

Keywords: consumer knowledge sharing; value co-creation; consumer purchase behavior; sustainable e-commerce; Facebook; PLS-SEM; IPMA matrix

\section{Introduction}

The recent years have witnessed the extreme popularity of social networks and social media applications, which have caused a progressive change in our daily life, especially for the younger generations.

Accordingly, online retail and e-commerce have adjusted to the normality of social media use; retailers are trying to draw customers towards their brands, and consumers are looking for an easy online shopping forum where they can share their thoughts and feedback.

However, to do so, retailers have to keep in mind the importance of e-commerce sustainability when making online transactions. Therefore, sustainable regulations should be taken into consideration when identifying consumer purchase perceptions [1] and when choosing the right social media marketing strategy.

In this regard, Dhaoui and Webster [2] introduced some actionable recommendations to design and implement an operative social media marketing strategy that can engage 
consumers positively. According to Nagy [3], e-commerce, with an $18 \%$ growth rate, represents the future of the retail sector in Hungary, where the majority of e-tailers (78\%) are actively involved in social media (mainly on Facebook). He also argued that $83 \%$ of internet users tend to navigate through Facebook frequently. Furthermore, according to current statistical data linked to the Hungarian population, in March 2021, 7.17 million people were using Facebook. Thus, Facebook is the most used platform in the country [4], because it allows for easy communication with family members and friends and promotes communication around common interests.

Indeed, there are unlimited advantages of social media for increasing the e-commerce field and helping users to link websites with their daily lives and business practices [5]. Correspondingly, social media offers the chance to assess products and services, make recommendations to others with the same interests, and link recent buying to future buying [6]. It also boosts consumers' socialization [5], which helps them to acquire skills, share knowledge, and integrate others' opinions through easy communication [7]. Nowadays, many organizations are highlighting the importance of knowledge sharing as a method for creating a competitive advantage and increasing performance, and this was also emphasized in many studies, such as the study in [8-11]. However, the previously mentioned authors did not consider all the benefits along with useful data from the Hungarian population, regarding their social media habits. Accordingly, Ho [12] believes that through Facebook, and by reinforcing brand trust and community identification, market players can increase their consumers' in-role and extra-role to attain financial benefits. In addition, Gamboa and Gonçalves [13] mention that Facebook is the best tool to encourage customers' relations and reinforce their loyalty, trust, satisfaction, and commitment, which can also impact their purchase behaviors thereafter.

Accordingly, previous studies focused on explaining the concept of $\mathrm{CPB}$ and highlighting its important role in the marketing field $[14,15]$. However, scholars mostly considered CPB in face-to-face transactions and the role of purchasers' emotions [16,17] that may influence the buying decision-making process. Along with this gap, and given the changes in the world and the rise of the internet of things, scholars have now changed their perspectives in this regard and have started to direct their attention to online purchases, shopping, and e-commerce $[18,19]$. Obviously, due to the actual environmental conditions, most customers have started using social commerce sites to make purchases, so that they can effortlessly share their favorite products/services, thoughts, and ideas and interact with other users by involving them in decision-making processes [6]. Consequently, the desire to collect information was the reason companies sought to supersede customers' needs and help consumers make the right purchasing decisions.

Furthermore, some other studies highlighted the significance of KS in purchasing intentions and the decision-making process $[6,20,21]$. However, the mediating role that value co-creation plays in these phenomena has not been investigated yet. Hence, this research was conducted to investigate how CKSB influences Hungarians' purchasing behaviors while using Facebook and to establish how value co-creation considered from its two principal dimensions, $\mathrm{CB}$ and $\mathrm{PB}$, mediates the link between $\mathrm{CKSB}$ and $\mathrm{CPB}$, together with the moderation role of gender, by dividing the population into female and male groups.

To go through all these facts, the quantitative study was informed by a questionnaire sent to 433 Facebook users within Hungary, who had made a minimum of one purchase through that social media platform. It was important to consider CKSB as an essential factor while making online purchases because it helps individuals have an idea about the products and services available, share their feedback and experiences, and help others in their decisions. Therefore, it was important to see the role of this variable from both consumer and business perspectives and go behind the traditional understanding of knowledge sharing, especially for making transactions through social media (Facebook).

This paper is structured with an initial literature review, where we have conceptualized our variables and showed the links between them to suggest the tested hypotheses. Then, we introduce our methodology and discuss the results of data analysis. To conclude, 
was present a summary of the theoretical and practical contributions and, finally, state the limitations and suggestions for future research.

\section{Literature Review and Hypotheses}

\subsection{CPB and Consumer Knowledge Sharing Behavior}

$\mathrm{CPB}$ is required to cover selecting, purchasing, and consuming goods and services for meeting needs and desires [22]. According to previous studies, CPB is a vast study field [23] informed by several factors that influence consumers' purchase decisions within online purchases [23]. According to the marketing literature, these factors can be determined through investigations on consumers' preferences to conceptualize marketing strategies [24]. Currently, investigators argue that CPB is about the personality and perspectives of consumers facilitating their purchase of goods and services on the market [25]. However, buyers have many choices and options, and it is not easy for companies to match the their demands and needs [26]. Correspondingly, the Internet has imposed many significant changes in the environment of purchasing in today's world. Therefore, consumers started to proceed with selling and buying transactions via social media platforms [27]. This increased use of social networks (Facebook, Twitter, Instagram, WhatsApp, YouTube, etc.) has given customers easy and rapid communication tools to share knowledge, ideas, needs, and requirements [25]. Thus, we strongly believe that social networks have also imposed significant changes in the $\mathrm{CPB}$, where earlier studies believed that social networks could influence the interactions and relationships between consumers and sellers, which could be used to determine consumers' behaviors, awareness, and attitudes [27].

Currently, ensuring a sustainable CPB has become a central issue. Sustainable consumer behavior has been presented as "a behavior that improves social and environmental performances as well as consumer well-being" [28]. This sustainable behavior is divided into two aspects: one is about the rational cognitive process and the other concerns the involuntary repetition of behaviors and the increase of habits toward sustainability. Accordingly, the appearance of new sustainable consumers obliged a change in buying and consuming intentions and processes. To reach long-term growth, therefore, companies and consumers should overlook the traditional forms of production and consumption and orientate themselves toward sustainable economies that respecting corporate values, business ethics, and corporate governance to face the current environmental and social challenges [29]. Nowadays, customers are more likely to be influenced and motivated not only by family and friends' perceptions but also by the amount of the shared information or knowledge through social media, including advertisements and other people's experiences, which considerably influence their purchasing behaviors.

In fact, knowledge is an important booster of competitive advantage and organizational development [30,31]. Certainly, the KS concept was established as a key element of knowledge management [32] because it can increase mutual learning, boost best practices for both purchasers and firms, increase knowledge creation, and facilitate innovation and productivity [33]. Given the significance of KS, no consensus has so far been made for conceptualizing a proper definition [34]. There have been consistent attempts to provide some related terms such as knowledge exchange, knowledge distribution, knowledge transaction, and knowledge diffusion [32]. Omotayo et al. [35] argue that KS can considered as peoples' interaction that requires an exchange of experiences and skills. Thus, it is an activity, or a process, used for transferring knowledge among people, communities, or organizations. When it comes to social media platforms, earlier researchers believe that these platforms resemble cyber "coffee shops" for people to meet and talk with others who share the same interests [36]. Therefore, these platforms facilitate the sharing of knowledge and experiences, gathering product information, acquiring data about consumption activity, and establishing social connections with other members.

The macro-environment is changing frequently and rapidly, and competition is higher than usual. Given the power of retailers and changing consumer demands, it is very important that companies start to foster long-term relationships with customers and cultivate 
different ways of thinking toward the success and sustainability of products [1]. In this respect, Civelek et al. [37] argue that social media is the one-way online communication instrument enabling firms to manage their marketing activities for boosting firm-customer relationships. Similarly, Nagy and Hadjú [38] believe that retailers should get to know their consumers and the extent of their trust in the use of artificial intelligence in webshops. Moreover, they believe that retailers should leverage this knowledge to promote customers' increased online spending and online purchasing given the significance of time and cost efficiency in shopping, which may also influence the customers' behaviors.

These transformations can lead to regular changes in consumers' ways of thinking, and their feelings and needs. Recent studies have demonstrated that purchase behavior is a personal behavior influenced by the flow of information [39]. According to some other studies, the key factor influencing this behavior is the growth of CKSB [12], verifying that more engagement of users in sharing knowledge through online communities will lead to greater purchase behaviors. Usually, consumers share their reviews about products, services, brands, producers, and even about retailers [40]. Consequently, it is possible to consult the community for suggestions and advice about options and the best prices [40]. Furthermore, people offer some information to others for troubleshooting if a product fails, which can enhance credibility, trustworthiness, and relevance [41]. Within virtual communities, it is also possible to have access to expert users for help in the purchasing decision-making process. $\mathrm{Xu}$ et al. [42] focused on the involvement of information release in the effect of $\mathrm{CPB}$ on social networking platforms and concluded that information disclosure could influence CPB positively. Similarly, Park et al. [43] introduced a conceptualized model demonstrating consumer engagement in purchasing luxury products through social media. They examined 282 samples to underline the impact of social media on increasing the purchase intention of luxury brands. From this perspective, we can suggest our first hypothesis:

\section{Hypothesis 1 (H1). CKSB significantly affects $C P B$.}

\subsection{Consumer Knowledge Sharing Behavior and Value Co-Creation Behavior}

Value creation is regarded as an important variable in marketing research. Several theories and conceptual frameworks have highlighted different methods for representing value as a phenomenon [44]. Value co-creation is thus defined as a process for establishing suitable service experiences for customers by exchanging knowledge between service companies and consumers [45]. Besides, it is defined as "the actions of several actors being unaware of each other contributing to each other's wellbeing" [46]. According to Kallmuenzer [47], interactions between firms and customers can foster KS, resource production, information exchange, and value creation for both firms and customers [45]. Some scholars believe that customers behave differently in value co-creation. Thus, Yi and Gong [48] categorized them into two factors: PB and CB.

$\mathrm{PB}$, defined as "the degree to which the customer is involved in producing and delivering the service" [49], is a strategy used by organizations to form closer connections with their customers [50]. To participate in service creation, purchasers use their knowledge and skills and share feedback and make suggestions for the improvement of a product [50]. To conclude, researchers believe that $\mathrm{PB}$ is an activity that consumers participate in for the production and delivery of services [50], hence, it is a part of consumer in-role deportment necessary for value co-creation [51]. Revilla-Camacho et al. [49] argue that customer's PB covers four dimensions: information seeking, information sharing, responsible behavior, and personal interaction. When customers sometimes replace employees in an organization by performing some tasks, they are considered to exhibit CB in that organization [52], which refers to "voluntary and discretionary behaviors that are not required for the successful production and/or delivery of the service but, in the aggregate, help the service organization " [53]. Therefore, researchers believe that CB is an optional extra-role deportment from customers and not necessary for value co-creation, but it helps in giving 
exceptional value to the firm [51]. These behaviors can appear when customers propose some developments for services, or serve other customers, or even contribute to sharing positive feedback through the word-of-mouth technique [54]. Thus, CB also covers the four dimensions of feedback, advocacy, helping, and tolerance [49].

The growth of social networks has also radically changed CKSB and organizations' behaviors. In online social network communities, users can collect professional knowledge, sort out problems, increase each other's capabilities, and make innovations [55]. Furthermore, firms believe that customers' interactions and assistance in product-support help them gather novel plans and new product ideas through KS in online communities [55]. Therefore, value co-creation can be used for theorizing the motive of KS [55].

Researchers claim that sharing feedback can be considered a form CB by customers [56]. Customers receiving high value from their experience are eager to share it with others, which reveals their high level of CB [46]. Regarding experience and personalization, studies show that well-treated purchasers usually offer optimistic feedback and disseminate them within their online communities. CB is also seen in advocacy by word-of-mouth and personal approval [57]. Blau [58] believes that the drivers for CB can be intrinsic, such as respect and affection, or extrinsic, such as earning money and delivering some free services or products [46]. Therefore, customers can provide some feedback to employees about the positive or negative features of their service (intrinsic reward). It is possible to show the mutuality of KS through positive word-of-mouth or by writing optimistic online reviews within social media, including Facebook, Instagram, etc., since customers can share their experiences or speak face-to-face with friends and relatives (intrinsic motive). Helping other customers is another instance of mutuality towards the organization with both extrinsic and intrinsic motives [46]. From this viewpoint, we can suggest our second hypothesis:

\section{Hypothesis 2 (H2). CKSB positively affects $C B$.}

Researchers believe that customers are a source of knowledge and highlight the importance of knowledge management [59]. It is possible to promote customers' trust, loyalty, and cooperation by managing their knowledge effectively [60]. Besides, Bulter [61] believes that employees can understand customers' needs by sharing knowledge, thereby increasing their satisfaction and augmenting the frequency and intensity of their buying and PB [59]. Since Facebook covers different communities, customer-employee interactions can contribute to knowledge sharing through discussions, helping them both find needed information. This would make it easier to enhance customers' involvement in cocreation and encourage them to develop a good relationship with the employees. Therefore, the CKSB would enable customers to foster a feeling of belonging whenever the group shares the same needs and ensures their commitment to being together [62]. Accordingly, we can suggest our third hypothesis:

\section{Hypothesis 3 (H3). CKSB significantly affects PB.}

\subsection{Value Co-Creation Behavior and CPB}

Via a self-administered questionnaire, Algharabat [63] gathered data from Jordanian consumer panel members and reported that telepresence positively influenced user engagement and could positively influence co-creation value and purchase intentions. It has also been reported that when consumers co-create a product in the virtual context [62], they tend to buy that product later. Thus, researchers believe that co-creation at the product design level strongly affects product innovativeness. Moreover, co-creation at the commercialization level significantly influences product sales. Therefore, value co-creation influences both purchase intention and behavior. This trend has been confirmed by various studies explaining that co-creation positively influences buying intention in specific contexts such as online communities [64] and luxury brands [65]. It has been reported that purchasers 
co-creating a new product tend to boost their emotional involvement [66] by releasing knowledge, offering feedback, and helping each other, which can make them important for the company $[67,68]$. When consumers are engaged in the company and in the production process, they can be advocates and come up with solutions for problems in a product. After spending a significant amount of time and effort, consumers will confirm that the product meets their needs [66]; hence, they will likely purchase the co-created product.

For service-based firms, consumers can be a substitute to employees to perform some tasks and activities that are beneficial for firms [69]. Moghadamzadeh et al. [70] confirm that $\mathrm{CB}$ and $\mathrm{CPB}$ on social media platforms can help companies render innovative services. $\mathrm{CB}$ can comprise of a retailer's service recommendation to others and consumers' further assistance [69]. It also covers customers releasing feedback and positive experiences with friends and relatives, treating service associates in a friendly way, and patiently bearing a service failure [71]. Thus, investigators aim to show how diverse kinds of customer CB can boost a firm's performance, leading to increased benefits for customers [72]. Furthermore, $\mathrm{CB}$ eases the purchase of many products, decreases the firm's costs, and continues to amplify the firm's service quality, ultimately augmenting CPB and their satisfaction. Thus, we can suggest our fourth hypothesis:

Hypothesis 4 (H4). CB positively affects $C P B$.

Some studies argue that the result of individual participation in online communities is linked with loyalty [12]. In a Facebook community, consumers' presence is linked to their communications and collaboration for purchasing reasons [73]. Besides, active communication and information sharing can manage the behaviors of Facebook users [74]. Thus, active interaction will enhance individuals' brand trust and nurture their feeling of comfort, which will increase their eagerness to purchase [75]. Moreover, some scholars argue that the regular presence of individuals in Facebook communities, either passively or actively, is influenced by the community values that gradually contribute to fostering the identification of a brand [12], hence, their purchasing behaviors can be augmented afterward. Accordingly, our fifth hypothesis is as follows:

Hypothesis 5 (H5). PB positively affects $C P B$.

Many studies report that volunteering involvement and customer $\mathrm{CB}$ are crucial factors for the easy functioning and long-term sustainability of brand services [76]. Studies have shown that these factors help brands to control their relationships with their customers, decreasing turnover intentions and boosting brand sustainability [77]. Concerning PB, several firms have tried to distinguish their business practices to attract customers and push them to play an active role in service production [78] since their involvement may increase brand loyalty.

Finally, our literature review suggests that sharing knowledge in the form of feedback, experiences, interests, and needs through online communities can heighten $\mathrm{CB}$ and $\mathrm{PB}$, leading to higher CPB. Therefore, our sixth and seventh hypotheses are as follows:

Hypothesis 6 (H6). $C B$ mediates the impacts of $C K S B$ on $C P B$.

Hypothesis 7 (H7). PB mediates the impacts of CKSB on CPB.

\subsection{Moderating Role of Gender}

Similar to Hwang and Kim [79], our study considers gender as a characteristic with which we can distinguish between males' and females' habits and actions. Previous studies have highlighted two important perspectives for gender, including biological sex, which explains the differences between males and females [80] and gender identity, which refers to psychological sex [81]. In this regard, prior research argues that gender can anticipate consumers' behaviors and influence their attitudes [82-84]. This thematic is explained by 
the fact that males and females have different decision-making processes, choices, habits, perspectives, and cognitive structures [79]. Hence, the gender variable has frequently been investigated as a moderator and considered from different angles in different fields.

In terms of the distinction between men and women, males are generally considered to be individualistic, tending to lead and master tasks with a high propensity toward assertiveness [85]. Contrarily, females are generally considered as sensitive, caring, and devoted, preferring to communicate rather than to master [85]. In addition, e-commerce researchers suggest that gender can have a central impact on online purchases and that men and women have completely different manners of interaction and different influences [86]. Male communication usually focuses on a hierarchy while females are more likely to be network-oriented. In general, women concentrate on creating intimacy while men focus on asserting independence and seeking respect [86]. From this perspective, we can suggest our eighth hypothesis:

Hypothesis 8 (H8). Gender plays a moderating role in the research model hypothesis.

The research model is shown in Figure 1.

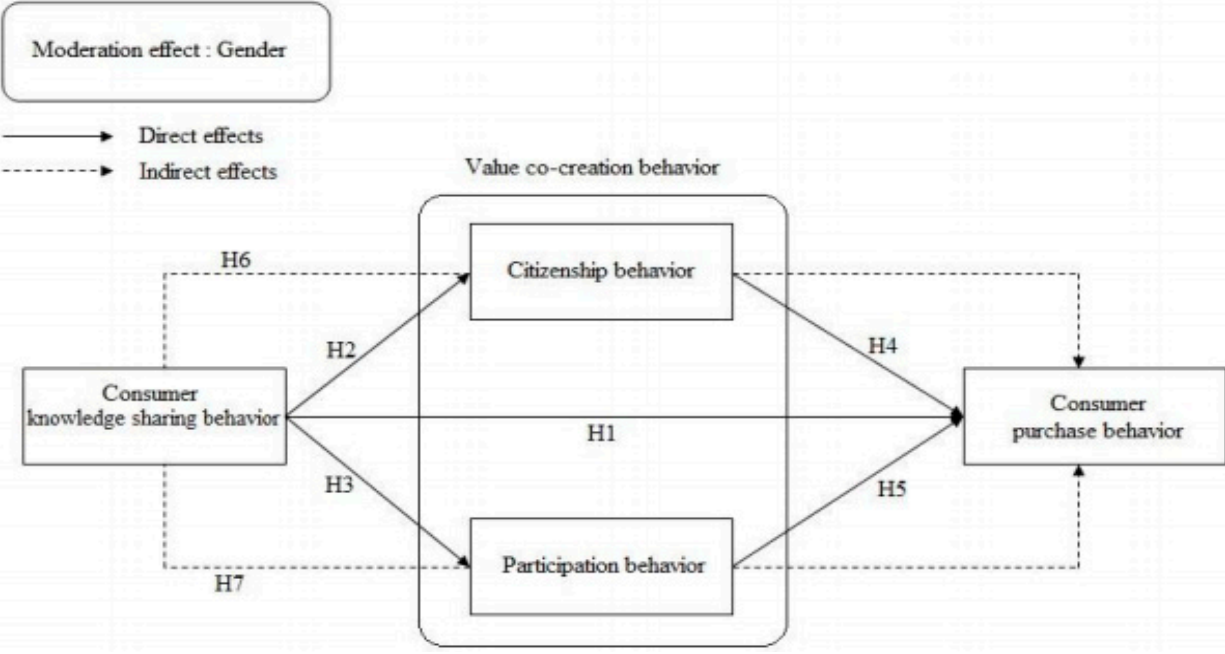

Figure 1. The research model.

\section{Materials and Methods}

This paper uses a quantitative or structured approach applied through a questionnaire separated into two parts. The first part covers some demographic information, and the second part consists of 20 items. It was conceptualized in English and translated into Hungarian. Accordingly, an established scale of measurement was used for all research variables, in which all items were scored based on a five-point Likert scale $(1=$ strongly disagree to $5=$ strongly agree). CKSB was determined through a four-item scale adapted from Hsu et al. [87], and CB was based on a six-item scale designed by Moghadamzadeh et al. [70]. For PB, a seven-item scale was used adapted from Moghadamzadeh et al. [70]. Lastly, CPB was based on a threeitem scale developed by Kumar et al. [26] and Ghahtarani et al. [6]. The exact descriptions of indicators (as items) regarding the abovementioned factors (as constructs) are shown in (Table 1).

The statistical population of this research included individuals living in Hungary with at least one online purchase experience. The questionnaire was distributed through different Facebook groups and channels to receive desirable feedback from respondents. It was also distributed through some professional networking sites such as LinkedIn. Data were collected for three months between 15 February until 15 May. The ICC coefficient was confirmed based on consistency and absolute agreement for verifying the questionnaire's content validity. The minimum sample size was not arbitrary in the PLS-SEM 
technique. PLS-SEM models were applied with a small sample size using bootstrapping methods. However, their results and accuracy were strongly dependent on the sample size [88]. Accordingly, the optimal sample size was settled based on specifications of the PLS-SEM models using the SPSS SamplePower sampling software.

Table 1. Measurement models, convergent validity, and reliability.

Variables and Items
CKSB
$($ AVE $=0.757$, C. alpha $=0.892$, Rho_A $=0.891, C R=0.925)$
CKSB1: I often take part in knowledge distribution activities in this online
community.

CKSB2: I typically devote a lot of time for knowledge distribution activities in this online community

CKSB3: When contributing to this online community, I typically enthusiastically share my knowledge with others.

CKSB4: When debating a complex issue, I am typically involved in the following interactions.

CB

$\left(\mathrm{AVE}=0.664, \mathrm{C}\right.$. alpha $\left.=0.901, \mathrm{Rho} \_\mathrm{A}=0.921, \mathrm{CR}=0.922\right)$

CB1: If a useful idea occurs to me for improving the service, I share it with the employee.

CB2: When I obtain good service from the employee or experience a problem, I comment about it and inform them.

CB3: I told optimistic things about their services and the employee to others.

CB4: I suggested XYZ to others to use their services.

CB5: I help other customers if they need my help.

CB6: If the employee is confused during service delivery, I will be tolerant.

PB

$(\mathrm{AVE}=0.713, \mathrm{C}$. alpha $=0.933$, Rho_A $=0.937, \mathrm{CR}=0.945)$

PB1: I have asked others and looked for information on where this service is located.

PB2: I evidently clarified what I needed the employee to do and answered all the employee's service questions.

PB3: I provided the employee with proper data so that they could do their duties.

PB4: I did all the anticipated tasks and behaviors.

PB5: I did responsibilities to the business and followed the employee's orders

PB6: I was welcoming and nice to the employee.

PB7: I was well-mannered and considerate to the employee.

\section{CPB}

$(\mathrm{AVE}=0.819, \mathrm{C}$. alpha $=0.889$, Rho_A $=0.895, \mathrm{CR}=0.932)$

CPB1: I aim to buy something on Facebook based on other comments.

CPB2: I aim to buy something on Facebook based on other consumers' sharing knowledge.

CPB3: I typically buy something on Facebook by considering other suggestions.

Outer Loadings

VIF

Model Type

Reflective

$\begin{array}{ll}0.899 & 2.528 \\ 0.890 & 3.212 \\ 0.902 & 3.229 \\ 0.783 & 1.619\end{array}$

Reflective

0.825

1.494

0.834

1.494

0.789

0.804

0.830

0.806

2.812

Reflective

0.771

1.968

0.836

3.305

0.866

3.806

0.834

2.607

0.808

2.315

0.894

3.633

0.893

3.643

0.891

3.346

0.949

0.874

Notes: CKSB, Consumer knowledge sharing behavior; CB, Citizenship behavior; PB, Participation behavior; CPB, Consumer purchase behavior; AVE, Average of Variance Extracted; C. alpha, Cronbach's alpha; Rho_A, Dillon-Goldstein's rho; CR, Composite Reliability; VIF, Variance Inflation Factor in items level.

The largest number (3) of variables in the set multivariate regression model showed a confidence level of $95 \%$, a power of increment of 0.95 , and an increment to R-squared of 0.05 . A minimum sample size of 331 was confirmed according to our research model. To ensure the validity of sampling and to obtain additional data, responses were gathered uninterruptedly. Eventually, 433 completed questionnaires were analyzed. Before the formal data collection process, a pilot study was also conducted to guarantee content validity and reliability from a 25-sample size. 
In the research sample, $60.3 \%$ and $39.7 \%$ of the respondents were men and women, respectively. Most of them (74.8\%) belonged to the 23-37 age group, and 39.7\% held Master's degrees, showing their high levels of education. Regarding Facebook use, many of the respondents (33.3\%) said they spent at least $1-2 \mathrm{~h}$ on this social media platform every day. Finally, we asked all the participants to respond to the questionnaire with full transparency and honesty.

\section{Results}

The model was estimated using the partial least squares structural equation modeling (PLS-SEM) method, which effectively deals with complex models, non-normal data, and small samples [89]. Measurement models were evaluated by SmartPLS 3 (version 3.3.3) software [90]. It is possible to apply PLS-SEM to both reflective and formative measurement models [91], and the former was confirmed based on the CTA analysis ( $p$-value > 0.05) [89,92-95]. Consequently, these models were applied for the evaluations. PLS-SEM gives fixed latent variable scores essential for running an IPMA. The latter compares the total effect of the structural model on a predictor variable with the predictors' average latent variable scores [90]. Significant variances were obtained in CPB (M = 3.159, $\mathrm{SD}=1.160), \mathrm{CB}(\mathrm{M}=3.585, \mathrm{SD}=0.985), \mathrm{PB}(\mathrm{M}=4.062, \mathrm{SD}=0.814)$, and $\mathrm{CKSB}(\mathrm{M}=2.790$, $\mathrm{SD}=1.120)$. Thus, the participants in this sample were significantly different in the extent to which they perceived the importance of the CPB perspective; hence, the sample was usable for testing our hypotheses.

\subsection{Evaluation of Measurement Models}

As shown in Table 1, Cronbach values, CR, and rho_A (Dillon-Goldstein's rho) values are above the threshold of 0.7 , revealing the internal consistency and reliability [92,96-100]. All the outer loading values were above the 0.7 threshold $[91,101,102]$. Meanwhile, the AVE scores were above a threshold of 0.50 revealing the internal consistency of the measurement model [89]. The AVE and outer loading values also presented the convergent validity of the measurement model. Before the analysis, it was vital to first confirm that collinearity was not a critical problem [89]. The VIF values were below a threshold value of 5, showing that collinearity was not a concern. Values less than 3 are considered ideal $[88,96]$.

Following Hair et al. [88] and Henseler et al. [101], the discriminant validity was assessed using the Heterotrait-Monotrait ratio of correlations (HTMT) (Table 2). All the HTMT ratios were below 0.85 , suggesting that the measurement model achieved discriminant validity. The plot of HTMT verified discriminant validity as well (Appendix A).

Table 2. Heterotrait-Monotrait Ratios (HTMT).

\begin{tabular}{ccccc}
\hline Construct & CB & CKSB & CPB & PB \\
\hline CB & & & & \\
CKSB & 0.580 & & \\
CPB & 0.423 & 0.479 & \\
PB & 0.566 & 0.220 & 0.358 \\
\hline
\end{tabular}

\subsection{Structural Model Assessment}

To obtain precise results, outlier data were tested before proceeding with the hypotheses. The FIMIX approach was applied to test the unobserved heterogeneity of the statistical population and to examine the robustness of the PLS-SEM method. FIMIX-PLS helped provide the model selection criteria and helped us determine the number of segments that we could retain from the data $[103,104]$. For this goal, the best criterion is Entropy Statistic Normed (EN), the value of which in our study (0.869) was positive and acceptable [104,105].

The significance of hypotheses was tested by a bootstrapping approach with 1000 resamples. CKSB displays a positive and significant impact on CPB $(\beta=0.332$, $\mathrm{CI}=[0.207 ; 0.450])$, consequently, confirming H1. CKSB displays a positive and significant impact on $\mathrm{CB}(\beta=0.550, \mathrm{CI}=492 ; 0.607])$, which verifies $\mathrm{H} 2$. CKSB has a positive and 
significant impact on $\mathrm{PB}(\beta=0.201, \mathrm{CI}=0.106 ; 0.290])$, thus confirming $\mathrm{H} 3$. $\mathrm{CB}$ insignificantly affects $\mathrm{CPB}(\beta=0.092, \mathrm{CI}=[-0.073 ; 0.256])$, thereby rejecting $\mathrm{H} 4$. $\mathrm{PB}$ has a positive and significant impact on $\mathrm{CPB}(\beta=0.226, \mathrm{CI}=0.093 ; 0.346])$, consequently, confirming H5 (Table 3). Appendix B represents the estimated model based on SmartPLS3 software.

Table 3. Results of the research hypotheses and the model fit.

\begin{tabular}{ccccccccc}
\hline Hypotheses & Direct Effect & SD & T-Statistics & $p$-Value & Low CL & High CL & Decision & Permutation Test $p$-Value \\
\hline H1 & 0.332 & 0.062 & $5.338^{* * *}$ & 0.000 & 0.207 & 0.450 & Supported & 0.541 \\
H2 & 0.550 & 0.030 & $18.587^{* * *}$ & 0.000 & 0.492 & 0.607 & Supported & 0.332 \\
H3 & 0.201 & 0.047 & $4.281^{* * *}$ & 0.000 & 0.106 & 0.290 & Supported & 0.886 \\
H4 & 0.092 & 0.085 & 1.088 & 0.277 & -0.073 & 0.256 & Not supported & 0.003 \\
H5 & 0.226 & 0.063 & $3.571^{* * *}$ & & 0.093 & 0.346 & Supported & 0.345 \\
H6 & 0.051 & 0.047 & 1.089 & 0.276 & -0.043 & 0.143 & Not supported & 0.004 \\
H7 & 0.045 & 0.016 & $2.806^{* *}$ & 0.005 & 0.017 & 0.078 & Supported & 0.355 \\
& & & & & & & \\
Model fit & $\mathrm{R}^{2}$ & $\mathrm{R}^{2}$ Adjusted & $\mathrm{Q}^{2}$ predict & & & & & \\
CPB & $25.5 \%$ & $24.9 \%$ & 0.176 & & & & & \\
CB & $30.3 \%$ & $30.1 \%$ & 0.298 & & & & & \\
PB & $4 \%$ & $3.8 \%$ & 0.034 & & & & & \\
\hline
\end{tabular}

Note: $\mathrm{t}>1.96$ at ${ }^{*} p<0.05 ; \mathrm{t}>2.58$ at ${ }^{* *} p<0.01 ; \mathrm{t}>3.29$ at ${ }^{* * *} p<0.001 ;$ two-tailed test for H6 and $\mathrm{H} 7$ specific indirect effect mentioned in the table.

As for $\mathrm{H6}$, the specific indirect effect of (CKSB-CB-CPB) is reflected as an insignificant impact $(\beta=0.051, C I=[106])$ and there is no mediation impact for this hypothesis. In H7, the specific indirect effect of (CKSB-PB-CPB) is reflected as a significant positive impact $(\beta=0.045, C I=[0.017 ; 0.078])$. Given the importance of the total impact $((\beta=0.428$, $\mathrm{CI}=[0.331 ; 0.514])$ and the direct effect, the presence of a partial mediation impact is supported for this hypothesis.

The R2 was determined to assess the in-sample model fit. The model explained $25.5 \%$ of the variance in CPB. Additionally, the out-of-sample predictive power was calculated using the PLS predict procedure with ten folds and ten repetitions $[98,106]$. As the Q2 predict value of $\mathrm{CPB}$ was above zero, the model has a predictive relevance. $\mathrm{CPB}$ was considered a target construct of the model. Since a linear model (LM) has a better root mean square error (RMSE) for all indicators of the target construct than the PLS-SEM benchmark (Table 4), the model has high predictive power. Besides, the NFI index or Bentler and Bonett indexes were applied here (NFI is 0.756 for this model). NFI led to values between 0 and 1 . An NFI closer to 1 reveals the better fitness of the model [98].

Table 4. PLS predict assessment of the manifest variable CPB.

\begin{tabular}{cccc}
\hline Items & RMSE $_{\text {PLS-SEM }}$ & RMSE $_{\text {LM }}$ & $\Delta$ RMSE \\
\hline CPB1 & 1.156 & 1.158 & -0.002 \\
CPB2 & 1.175 & 1.174 & 0.001 \\
CPB3 & 1.235 & 1.332 & -0.097 \\
\hline
\end{tabular}

Notes: RMSE = root mean squared error; gray-shaded results = the predictive power of PLS-SEM is lower than that of the LM benchmark.

\subsection{Moderating Role of Gender}

The measurement invariance of the composite model (MICOM) procedure suggested by Hair et al. [92] was applied in this study. MICOM covers three stages: (i) configural invariance assessment, (ii) compositional invariance assessment, and (iii) the evaluation of equal means and variances. Step 1 mostly focuses on setting the configural invariance for guaranteeing that each latent variable in the PLS path model has been specified equally for all the groups. Configural variance exists when constructs are uniformly parameterized and estimated across groups. An initial qualitative evaluation of the specifications of latent variables is then compulsory across all the groups (Hair et al.) [92]. In step 2, compositional invariance can be assumed if the test yields a $p$-value larger than 0.05 . In step 3 , full measurement invariance is set if no significant differences are observed in mean 
values and (logarithms of) variances across the groups. The results (Table 5) display evidence of partial measurement invariance, enabling us to compare the standardized coefficients across the two groups of gender. For assessing the moderating role of gender (H8), the permutation test approach was used to compare male and female groups. Given $p$-value $>0.05$ and confidence intervals (see Table 3), no significant differences are observed between these two types of media in the research sample, except for $\mathrm{H} 4$ and $\mathrm{H} 6$ hypotheses.

Table 5. MAICOM test.

\begin{tabular}{cccc}
\hline & Step 2. Compositional Invariance Test using Permutation & \\
\hline C $=\mathbf{1}$ & $\mathbf{9 5 \%}$ CI & CIE? \\
CB & 0.998 & {$[0.997 ; 1.000]$} & Yes \\
CKSB & 0.998 & {$[0.999 ; 1.000]$} & Yes \\
CPB & 0.995 & {$[0.996 ; 1.000]$} & Yes \\
PB & 0.997 & {$[0.995 ; 1.000]$} & Yes \\
\hline & Step 3. Equal Mean Assessment & \\
\hline CB & $\mathbf{D}=\mathbf{0}$ & $\mathbf{9 5 \%}$ CI & EMV? \\
CKSB & 0.209 & {$[-0.188 ; 0.193]$} & No \\
CPB & 0.394 & {$[-0.202 ; 0.211]$} & No \\
PB & 0.059 & {$[-0.197 ; 0.209]$} & No \\
\hline & -0.269 & {$[-0.195 ; 0.194]$} & \\
\hline CB & Step 3. Equal Variance Assessment & EV? \\
\hline CKSB & $\mathbf{R}=\mathbf{0}$ & $\mathbf{9 5 \%}$ CI & No \\
PB & -0.493 & {$[-0.297 ; 0.295]$} & No \\
\hline
\end{tabular}

Notes: $\mathrm{C}=1$ : correlation value $=1$; CI: confidence interval; CIE: compositional invariance established? $\mathrm{D}=0$ : difference in the composite's mean value $(=0)$; $C I$ : confidence interval; EMV: equal Mean values; $\mathrm{R}=0$ : $\operatorname{logarithm}$ of the composite's variances ratio $(\mathrm{R}=0)$; $\mathrm{CI}$ : confidence interval; $\mathrm{EV}$ : equal variances.

\subsection{Importance-Performance Map Analysis (IPMA)}

IPMA presents a contrast of importance (i.e., the total effect of predecessor constructs in predicting a target construct) and performance (i.e., average latent variable scores). Consequently, IPMA is advantageous for identifying predecessors with relatively low performance but high importance for the target constructs [103]. In this study, our target construct is $\mathrm{CPB}$ predicted by three predecessors.

It is shown that "CKSB" has the highest importance score of 0.428 ; if consumers augment their CKSB performance by one unit point, the overall CPB will increase by 0.428 . Furthermore, our results display that the lowest performance (44.749) is linked to CKSB showing a great opportunity for expansion in this area (Table 6). Figure 2 reveals the IPMA matrix connected to variables, and Figure 3 deals with items based on importance and performance.

Table 6. Importance-performance map analysis.

\begin{tabular}{ccc}
\hline Latent variables & Importance & Performance \\
\hline CKSB & 0.428 & 44.749 \\
CB & 0.092 & 64.293 \\
PB & 0.226 & $\mathbf{7 6 . 9 0 9}$ \\
\hline
\end{tabular}

Note: All total effects (importance) larger than 0.10 are significant at an $\alpha \leq 0.10$ level. The bold values indicate the highest importance (total effect) and highest performance values. 


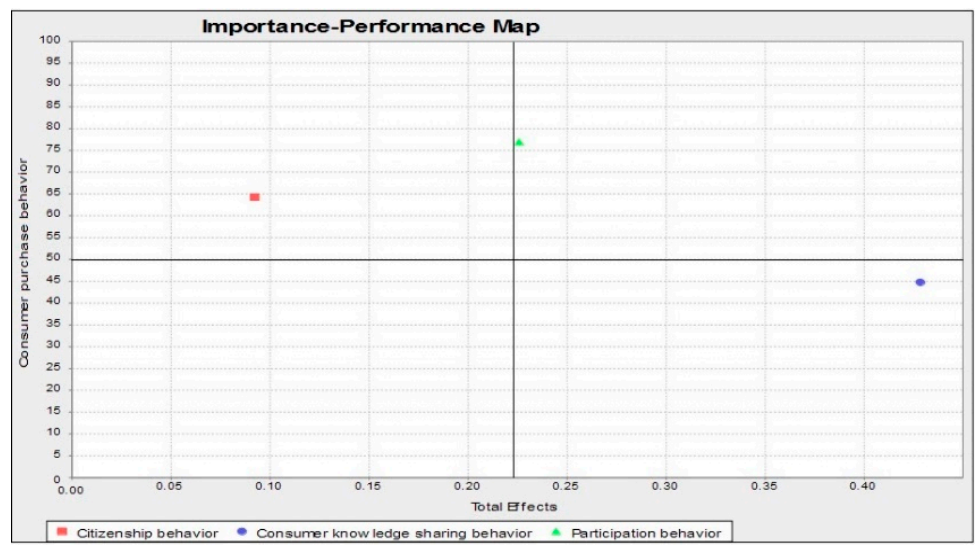

Figure 2. The IPMA matrix with the target of CPB (Consumer Purchase Behavior- Constructs' level).

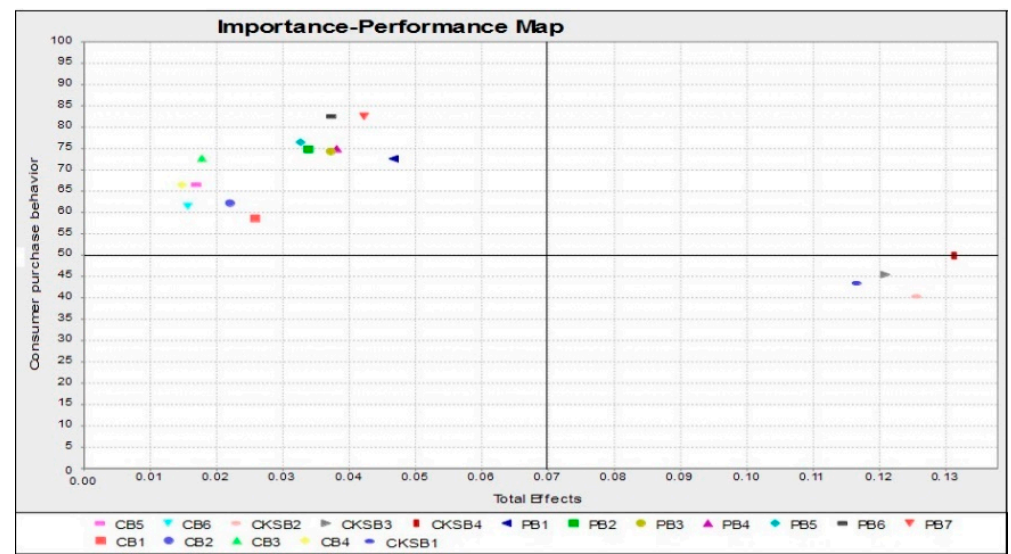

Figure 3. The IPMA matrix with the target of CPB (Consumer Purchase Behavior-Items' level).

\section{Discussion}

This paper aims at shedding light on the impact of CKSB on CPB through the mediating role of the two dimensions of value co-creation, namely, CB and PB. Earlier, these concepts have attracted attention in previous research that concentrated on stating the heroic approach of KS, considering that it is based on the flow of information and purchasers' emotional process in social networking sites [39]. This is because it can help connect consumers who can share their experience around products, services, brands, producers, and even experiences with retailers [40]. Consequently, it is possible to consult social media communities to look for suggestions and assistance about choice options and best prices [40]. This significant connection between the two variables of CKSB and CPB was established in the IPMA matrix. According to our verification, an increased use of social networks allows consumers to feel more comfortable communicating their knowledge, ideas, and needs. This was also confirmed in Hungary, where customers mostly share their knowledge and purchasing experiences through Facebook (registered as the most used social media platform in Hungary), which has an effect on their CB and PB.

As mentioned above, and from an empirical perspective, this study focuses on highlighting the significant connection between CKSB and CPB. Then, our findings showed that this link was verified in the first hypothesis, which corroborates the studies of Hameed et al. [30], Afshar Jalili and Ghaleh [32], and Philsoophian et al. [33]. These studies claim that the KS concept is the main element for boosting mutual learning, persuading best practices for both purchasers and firms, enhancing knowledge creation, and easing innovation and productivity. They also report that KS is a relevant method in social interactions to involve more users through online communities and promote their purchasing behaviors. In addition, our results agree with the studies of $\mathrm{Xu}$ et al. [42] and Park et al. [43], who argue that information disclosure considerably affects $\mathrm{CPB}$. Second, since value co-creation was a vital element in marketing 
theory and was introduced as a phenomenon by many different theoretical approaches [47], our research aimed to test the connection between the two dimensions (CB and PB) and CKSB in the second and third hypotheses. The results revealed a positive significant effect with both dimensions, confirming the studies of Assiouras et al. [46] and Lee et al. [59], who argue that customers receiving high value from their experience tend to share it with others, indicating a high level of CB. Therefore, CKSB via online communities helps customers feel that they are important to the group. This could be produced by sharing feedback with employees or by helping other customers. They also confirm the study of Koenig and Srikantaiah [60], arguing that customers' effective knowledge sharing can boost their commitment, trust, loyalty, and collaboration. This fact was also mentioned by Bulter [61], stating that releasing knowledge helps employees recognize customers' needs and desires so that they are able to increase their satisfaction in co-creation participation.

Third, we verified the connection between the dimensions of value co-creation with $\mathrm{CPB}$. The results revealed two diverse aspects: the insignificant impact of $\mathrm{CB}$ on $\mathrm{CPB}$ and the significant positive impact of $\mathrm{PB}$ on $\mathrm{CPB}$. These findings were confirmed in the studies of Guzel et al. [66] and Lee and Kim [67], explaining that purchasers who participate in co-creating a new product tend to enhance their emotional involvement by releasing knowledge, giving feedback, and helping others; this encourages them to feel more valued by the company. Therefore, the more consumers are involved in the production process, the greater the buying tendency of the co-created product will be. Hence, a positive impact of $\mathrm{PB}$ was confirmed on $\mathrm{CPB}$. However, the rejected relationship between $\mathrm{CB}$ and $\mathrm{CPB}$ may be explained by the fact that customers' $\mathrm{CB}$ only helps organizations, and this involvement is not required for the success of the production or delivery process. Therefore, feedback, advocacy, helping, or even tolerance are considered as beneficial for an organization's performance but not needed for increasing or changing CPB. Thus, our fourth Hypothesis (H4) was rejected.

The mediating role of the two dimensions of value co-creation led to two different results. The first was the rejection of $\mathrm{CB}$ mediation (H6) as our data confirmed only the link between $\mathrm{CKSB}$ and $\mathrm{CB}$ and rejected the link between $\mathrm{CB}$ and $\mathrm{CPB}$ because customers usually share their feedback, help, or tolerate some problems to participate in the business success / failure from the organization's perspective, not from the customer's. Moreover, the validation of PB mediation (H7) corroborates the study of Ngo and O'Cass [78], who argue that many firms are trying to pay careful attention to differentiate their business practices to persuade their customers to take part in the service production. This is clarified by the fact that their contribution will keep them closer to the brand. This paper also tries to study the moderating impact of gender in the relationships between the chosen variables confirmed in Hypothesis 8 (H8). In fact, the results in $\mathrm{H} 4$ revealed a significant difference between females and males in their KS behaviors, $\mathrm{CB}, \mathrm{PB}$, and purchasing approaches. This corroborates the study of Sanchez-Franco et al. [107], who argue that the link between commitment and loyalty is affected by gender according to self-efficacy, and the study of Mitchell and Walsh [108], who argue that males and females look for diverse products and tend to have different ways of thinking, which affects their purchase behaviors.

To summarize, our findings confirm that $\mathrm{CKSB}$ positively affects $\mathrm{CPB}, \mathrm{CB}$, and $\mathrm{PB}$ as suggested in $\mathrm{H} 1, \mathrm{H} 2$, and $\mathrm{H} 3$. It also confirms that $\mathrm{PB}$ positively influences $\mathrm{CPB}$, as shown in $\mathrm{H} 5$. As confirmed by $\mathrm{H} 3$ and $\mathrm{H} 5$, the mediation effect of $\mathrm{PB}$ was also verified in H6. However, the rejection of $\mathrm{H} 4$ was because of our conclusion on the absence of a significant effect between $\mathrm{CB}$ and $\mathrm{CPB}$, which also confirms the rejection of the mediation impact of $\mathrm{CB}$ in $\mathrm{H7}$. Finally, the validation of $\mathrm{H} 8$ reveals the moderating role of gender in our research model.

\section{Conclusions}

This paper offers some theoretical and managerial contributions. First, the study was done in the Hungarian context using Facebook communities to examine purchase intentions, which was not well documented previously. Consequently, this goes behind a 
new conceptualization of CKSB, exceeding the traditional KS method within face-to-face purchase transactions [16]. Second, despite some investigations on the vital role of KS in e-commerce and online purchases through social media, an empirical gap was detected since the significance of the dimensions of value co-creation mediating the connection between CKSB and CPB was considered in none of these studies.

According to the IPMA results, CKSB registered the highest significance, but that was not the case for $\mathrm{CPB}$ variable, which has correspondingly shown a lower performance than CKSB. From this perspective, the mentioned issue should be considered as a very important managerial implication that deserves consideration by managers of online businesses. Likewise, the IPMA matrix reveals that CKSB items are very important; however, their performance was not satisfactory in our statistical population. In other words, "Taking part in more CKSB activities in the online community", "Doing CKSB activities in the online community", "Sharing CKSB with other users", and "Interacting with other users" are the important items that should be considered to boost CPB in online communities within a Hungarian context.

Facebook is one of the most popular online social media platforms in Hungary. Online business managers should pay attention to knowledge sharing as an important factor affecting $\mathrm{CPB}$ within this platform. Modifying CPB based on CKSB is a significant point of interest, necessitating additional studies in this area. Another significant point is the regulating role of gender. According to some reports, men and women are different in terms of the effect of $C B$ on $C P B$. The increase in items of $C P$ results in positively increased $\mathrm{CPB}$ in a group of men. Nevertheless, $\mathrm{CPB}$ decreased when raising awareness of $\mathrm{CB}$ items among women. Since the items of $\mathrm{CB}$ include the interaction with employees of online businesses, men and women obtain positive and negative feedback, respectively. Online business managers should consider this important point and correctly examine the cause of this issue.

This research has several limitations. First, it is not possible to study causal relationships without the risk of bias. This problem cannot be removed despite the approximation of the complete collinearity and the validation of the stated links between our variables based on the literature review, which can be explained using a cross-sectional design and a survey that was probably influenced by the COVID-19 pandemic. To deal with this issue, upcoming studies can use longitudinal research to analyze associations between variables and offer well-grounded results. Second, this study was performed only within the Hungarian population, which reduces the generalizability of our research, considering the small sample size and the difficulty in gathering adequate responses. Accordingly, future investigations should enhance this issue of the empirical results by choosing another scale, using the probabilistic sampling method, and repeating the study model in other countries. Fourth, we believe that a qualitative study can be done in the future for identifying the reasons of negative feedback from women interacting with CB items in online businesses on Facebook. Fifth, we highly recommend studying our research model by adding novel mediating and moderating variables and even comparing Facebook with other social media platforms to consider the best platform that engages consumers with awareness around sustainability in e-commerce. It is possible to add the media type variable to the research model and test the model as a moderated mediation model. Another possible research area can be the social media usage habits of the largest commercial corporations in both Hungary and around the world, and their effects on the CPB. Despite the use of a standard questionnaire in our study, there are some research items that contain double-barreled bias. Hence, future researchers should be careful about using these items.

Author Contributions: Conceptualization, P.E., K.A.H. and M.F.-F.; methodology, P.E. and E.G.H.; software, P.E.; validation, P.E., K.A.H. and H.Z.; formal analysis, P.E.; investigation, K.A.H. and E.G.-H.; resources, M.F.-F.; data curation, K.A.H.; writing-original draft preparation, K.A.H., P.E. and H.Z.; writing-review and editing, K.A.H., P.E. and H.Z.; visualization, P.E.; supervision, M.F.-F.; project administration, M.F.-F.; funding acquisition, M.F.-F. All authors have read and agreed to the published version of the manuscript. 
Funding: This research received no external funding.

Institutional Review Board Statement: Not applicable.

Informed Consent Statement: Not applicable.

Data Availability Statement: The study did not report any external data.

Conflicts of Interest: The authors declare no conflict of interest.

\section{Appendix A}

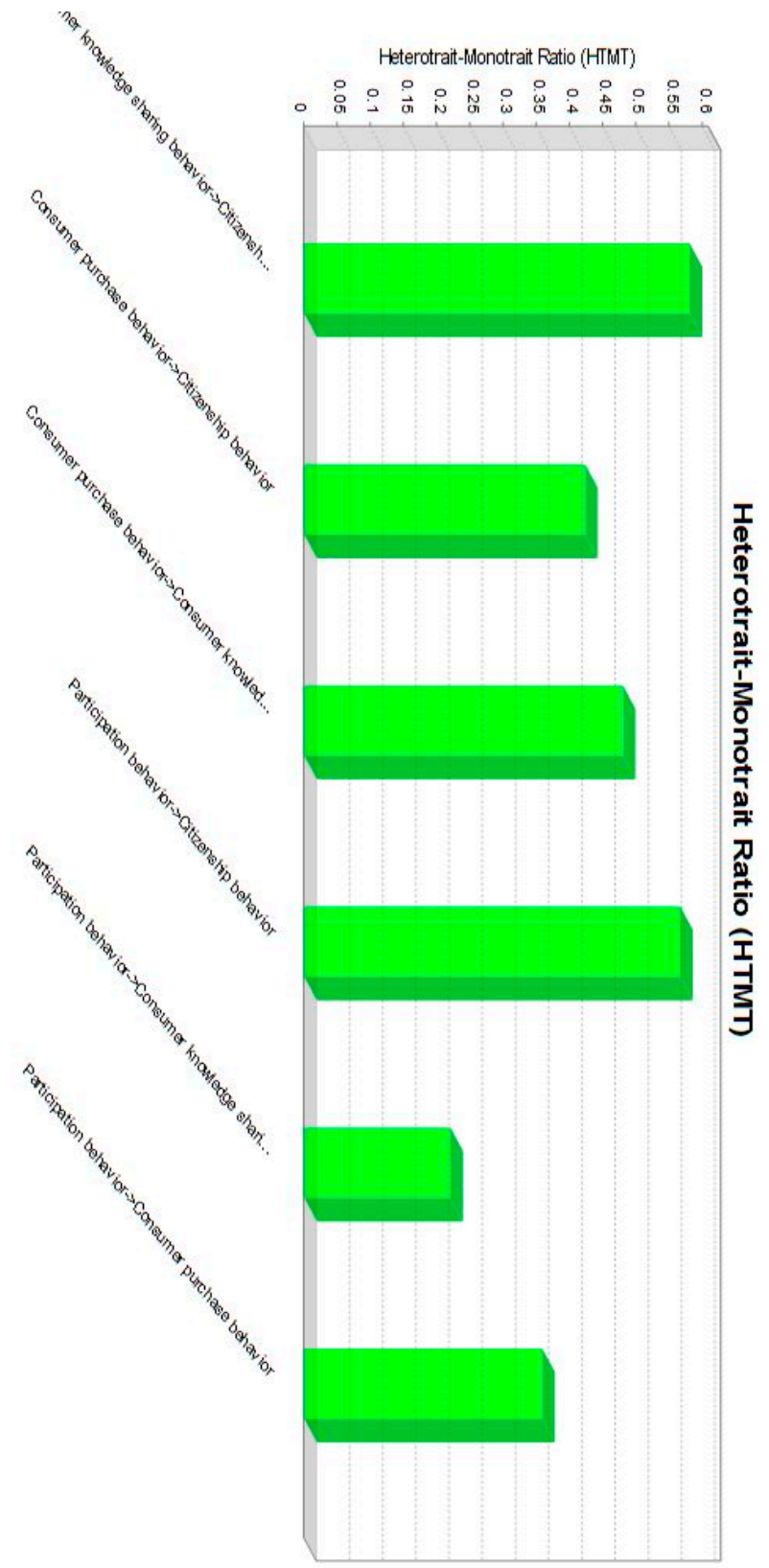

Figure A1. The Plot of discriminant validity in constructs level. 


\section{Appendix B}

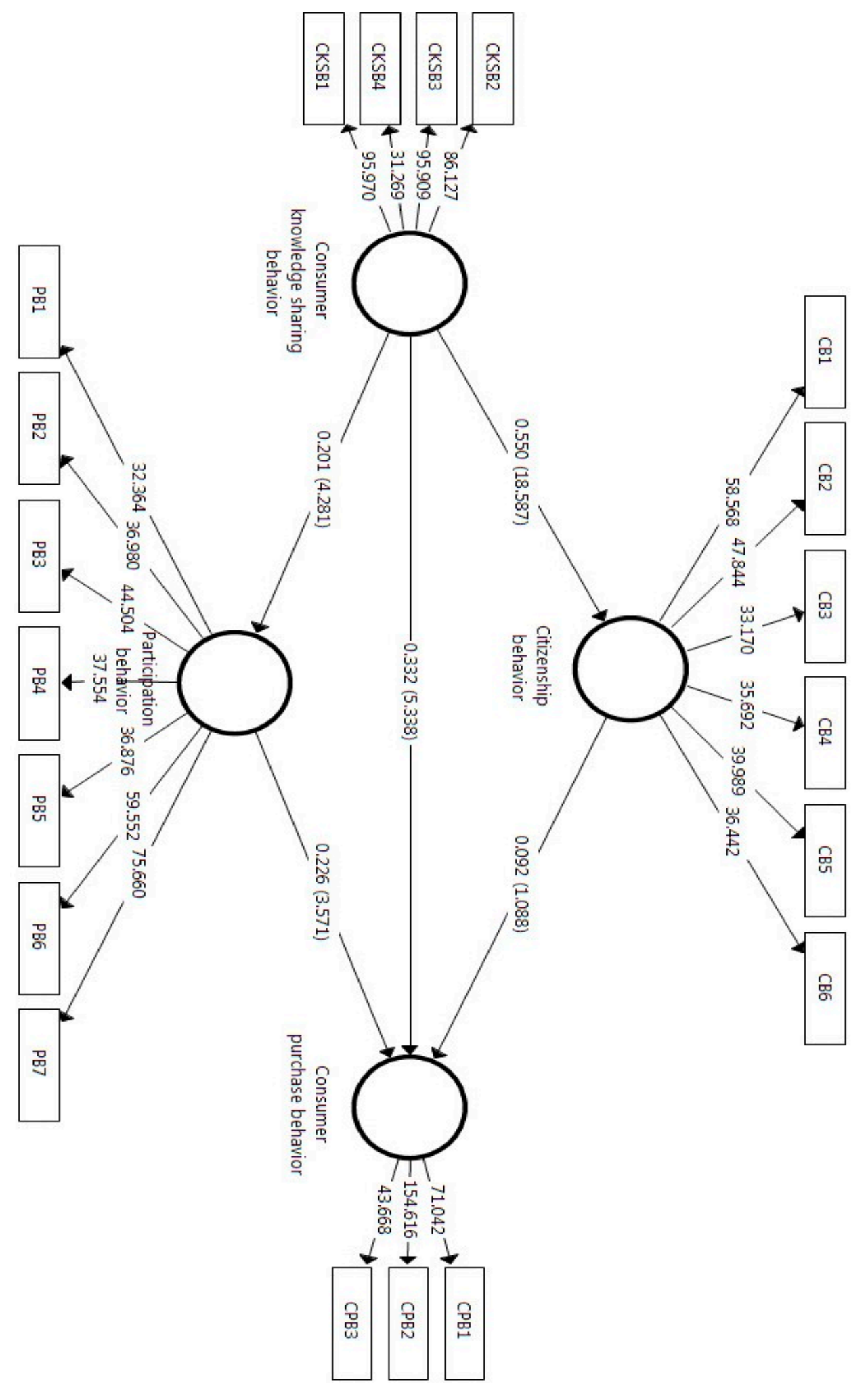

Figure A2. Path coefficients and T-statistics model. 


\section{References}

1. Oláh, J.; Kitukutha, N.; Haddad, H.; Pakurár, M.; Máté, D.; Popp, J. Achieving sustainable e-commerce in environmental, social and economic dimensions by taking possible trade-offs. Sustainability 2019, 11, 89. [CrossRef]

2. Dhaoui, C.; Webster, C.M. Brand and consumer engagement behaviors on Facebook brand pages: Let's have a (positive) conversation. Int. J. Res. Mark. 2021, 38, 155-175. [CrossRef]

3. Nagy, S. E-commerce in Hungary: A market analysis. Theory Methodol. Pract. 2016, 12, 25-32. [CrossRef]

4. Statista. Number of Facebook Users in Hungary from September 2018 to March 2021. Available online: https: / /www.statista. com/statistics/1029770/facebook-users-hungary (accessed on 10 April 2021).

5. Okazaki, S. The tactical use of mobile marketing: How adolescents' social networking can best shape brand extensions. J. Advert. Res. 2009, 49, 12-26. [CrossRef]

6. Ghahtarani, A.; Sheikhmohammady, M.; Rostami, M. The impact of social capital and social interaction on customers' purchase intention, considering knowledge sharing in social commerce context. J. Innov. Knowl. 2020, 5, 191-199. [CrossRef]

7. Wang, X.; Yu, C.; Wei, Y. Social media peer communication and impacts on purchase intentions: A consumer socialization framework. J. Interact. Mark. 2012, 26, 198-208. [CrossRef]

8. Nathan, R.J.; Yi, C.X.; Görgényi, É.H.; Victor, V.; Gonda, G.; Farkas, M.F. Impact of knowledge and innovation management to firm financial and non-financial performance. Vadyb. J. Manag. 2019, 71, 71-81.

9. Azeem, M.; Ahmed, M.; Haider, S.; Sajjad, M. Expanding competitive advantage through organizational culture, knowledge sharing and organizational innovation. Technol. Soc. 2021, 66, 101635. [CrossRef]

10. Tran, T.K.P. The Effect of Knowledge Sharing and Innovativeness on Organizational Performance: An Empirical Study in Vietnam. J. Asian Financ. Econ. Bus. 2021, 8, 503-511.

11. Pranowo, A.S.; Dachi, A.; Nasution, N.L.; Ende, E.; Hendayana, Y. The Mediating Role of Innovation Capability in the Relationship between Knowledge Sharing on SMEs' Performance. Bp. Int. Res. Crit. Inst. (BIRCI-J.) Soc. Sci. 2021, 4, 3890-3899.

12. Ho, C.-W. Consumer behavior on Facebook: Does consumer participation bring positive consumer evaluation of the brand? EuroMed J. Bus. 2014, 9, 252-267. [CrossRef]

13. Gamboa, A.M.; Gonçalves, H.M. Customer loyalty through social networks: Lessons from Zara on Facebook. Bus. Horiz. 2014, 57, 709-717. [CrossRef]

14. Tandon, A.; Kaur, P.; Bhatt, Y.; Mäntymäki, M.; Dhir, A. Why do people purchase from food delivery apps? A consumer value perspective. J. Retail. Consum. Serv. 2021, 63, 102667. [CrossRef]

15. Cheung, M.F.; To, W. The effect of consumer perceptions of the ethics of retailers on purchase behavior and word-of-mouth: The moderating role of ethical beliefs. J. Bus. Ethics 2020, 171, 1-18. [CrossRef]

16. Sherman, E.; Mathur, A.; Smith, R.B. Store environment and consumer purchase behavior: Mediating role of consumer emotions. Psychol. Mark. 1997, 14, 361-378. [CrossRef]

17. Helmefalk, M.; Hultén, B. Multi-sensory congruent cues in designing retail store atmosphere: Effects on shoppers' emotions and purchase behavior. J. Retail. Consum. Serv. 2017, 38, 1-11. [CrossRef]

18. Park, C.H.; Kim, Y.G. Identifying key factors affecting consumer purchase behavior in an online shopping context. Int. J. Retail Distrib. Manag. 2003, 31, 16-29. [CrossRef]

19. Yin, W.; Xu, B. Effect of online shopping experience on customer loyalty in apparel business-to-consumer ecommerce. Text. Res. J. 2021, 00405175211016559. [CrossRef]

20. Yoo, F.; Jung, H.J.; Oh, K.W. Motivators and barriers for buying intention of upcycled fashion products in China. Sustainability 2021, 13, 2584. [CrossRef]

21. Xu, Z.; Liu, Y. Multi-modal information learning and analytics of cross-media big data. Expert Syst. 2019, 46, e12446.

22. Ramya, N.; Ali, S.M. Factors affecting consumer buying behavior. Int. J. Appl. Res. 2016, 2, 76-80.

23. Qazzafi, S. Factor affecting consumer buying behavior: A conceptual study. Int. J. Sci. Res. Dev. 2020, 8, 1205-1208.

24. Auf, M.A.A.; Meddour, H.; Saoula, O.; Majid, A.H.A. Consumer buying behaviour: The roles of price, motivation, perceived culture importance, and religious orientation. J. Bus. Retail Manag. Res. 2018, 12, 177-186. [CrossRef]

25. Goh, J.W.; Ng, A.H.H. Factors Affecting Online Consumer Buying Behavior towards Essential Oils in Penang. In Impact of Globalization and Advanced Technologies on Online Business Models; IGI Global: Hershey, PA, USA, 2021; pp. $279-302$.

26. Kumar, A.; Taunk, A. Factors Influencing Buying Behaviour of the Consumers: A Study of Four-Wheeler Passenger Tourist Cab State of Uttarakhand. Int. J. Res. Humanit. Soc. Stud. 2018, 5, 36-40.

27. Nash, J. Exploring how social media platforms influence fashion consumer decisions in the UK retail sector. J. Fash. Mark. Manag. Int. J. 2019, 24, 83-103. [CrossRef]

28. Elhoushy, S.; Lanzini, P. Factors affecting sustainable consumer behavior in the MENA region: A systematic review. J. Int. Consum. Mark. 2021, 33, 256-279. [CrossRef]

29. Orîndaru, A.; Popescu, M.-F.; Căescu, Ș.-C.; Botezatu, F.; Florescu, M.S.; Runceanu-Albu, C.-C. Leveraging COVID-19 Outbreak for Shaping a More Sustainable Consumer Behavior. Sustainability 2021, 13, 5762. [CrossRef]

30. Hameed, Z.; Khan, I.U.; Sheikh, Z.; Islam, T.; Rasheed, M.I.; Naeem, R.M. Organizational justice and knowledge sharing behavior: The role of psychological ownership and perceived organizational support. Pers. Rev. 2019, 48, 748-773. [CrossRef]

31. Berraies, S.; Hamza, K.A.; Chtioui, R. Distributed leadership and exploratory and exploitative innovations: Mediating roles of tacit and explicit knowledge sharing and organizational trust. J. Knowl. Manag. 2020, 25, 1287-1318. [CrossRef] 
32. Jalili, Y.A.; Ghaleh, S. Knowledge sharing and the theory of planned behavior: A meta-analysis review. VINE J. Inf. Knowl. Manag. Syst. 2020, 51, 236-258.

33. Philsoophian, M.; Akhavan, P.; Ghorbani, S.; Afshar, Y. The Delphi Method for Selection of KM Strategies Based on the Level of KM Maturity: A Case of OICO, Iran. IUP J. Knowl. Manag. 2016, 14, 7-17.

34. Jalili, Y.A. I rather share my knowledge: Applying gamification approach and nudge theory to develop an incentive system. VINE J. Inf. Knowl. Manag. Syst. 2019, 46, 203-215.

35. Omotayo, F.O.; Babalola, S.O. Factors influencing knowledge sharing among information and communication technology artisans in Nigeria. J. Syst. Inf. Technol. 2016, 18, 148-169. [CrossRef]

36. Ayeh, J.K.; Au, N.; Law, R. Do we believe in TripAdvisor? Examining credibility perceptions and online travelers' attitude toward using user-generated content. J. Travel Res. 2013, 52, 437-452. [CrossRef]

37. Civelek, M.; Gajdka, K.; Světlík, J.; Vavrečka, V. Differences in the usage of online marketing and social media tools: Evidence from Czech, Slovakian and Hungarian SMEs. Equilibrium. Q. J. Econ. Econ. Policy 2020, 15, 537-563. [CrossRef]

38. Nagy, S.; Hajdú, N. Consumer Acceptance of the Use of Artificial Intelligence in Online Shopping: Evidence from Hungary. Amfiteatru Econ. 2021, 23, 155-173.

39. Peña-García, N.; Gil-Saura, I.; Rodríguez-Orejuela, A.; Siqueira-Junior, J.R. Purchase intention and purchase behavior online: A cross-cultural approach. Heliyon 2020, 6, e04284. [CrossRef]

40. De Valck, K. Virtual communities of consumption: Networks of consumer knowledge and companionship. Ph.D. Thesis, Erasmus Research Institute of Management, Rotterdam, The Netherlands, 2005.

41. Bone, P.F. Determinants of word-of-mouth communications during product consumption. ACR N. Am. Adv. 1992, 19, 579-583.

42. Xu, X.; Zeng, S.; He, Y. The impact of information disclosure on consumer purchase behavior on sharing economy platform Airbnb. Int. J. Prod. Econ. 2021, 231, 107846. [CrossRef]

43. Park, J.; Hyun, H.; Thavisay, T. A study of antecedents and outcomes of social media WOM towards luxury brand purchase intention. J. Retail. Consum. Serv. 2021, 58, 102272. [CrossRef]

44. Grönroos, C.; Strandvik, T.; Heinonen, K. Value co-creation: Critical reflections. In The Nordic School: Service Marketing and Management for the Future; Hanken School of Economics: Helsinki, Finland, 2015; pp. 69-81.

45. Yen, C.-H.; Teng, H.-Y.; Tzeng, J.-C. Innovativeness and customer value co-creation behaviors: Mediating role of customer engagement. Int. J. Hosp. Manag. 2020, 88, 102514. [CrossRef]

46. Assiouras, I.; Skourtis, G.; Giannopoulos, A.; Buhalis, D.; Koniordos, M. Value co-creation and customer citizenship behavior. Ann. Tour. Res. 2019, 78, 102742. [CrossRef]

47. Kallmuenzer, A. Exploring drivers of innovation in hospitality family firms. Int. J. Contemp. Hosp. Manag. 2018, 30, 1978-1995. [CrossRef]

48. Yi, Y.; Gong, T. Customer value co-creation behavior: Scale development and validation. J. Bus. Res. 2013, 66, 1279-1284. [CrossRef]

49. Dabholkar, P.A. How to improve perceived service quality by increasing customer participation. In Proceedings of the 1990 Academy of Marketing Science (AMS) Annual Conference, New Orleans, LA, USA, 25-29 April 1990; Academy of Marketing Science (Springer): Cullowhee, NC, USA, 2015.

50. Revilla-Camacho, M.Á.; Vega-Vázquez, M.; Cossío-Silva, F.J. Customer participation and citizenship behavior effects on turnover intention. J. Bus. Res. 2015, 68, 1607-1611. [CrossRef]

51. Shamim, A.; Ghazali, Z. Customer Participation in Value Co-Creation: Can it Develop Corporate Brand Experience? Adv. Sci. Lett. 2015, 21, 1197-1201. [CrossRef]

52. Delpechitre, D.; Beeler-Connelly, L.L.; Chaker, N.N. Customer value co-creation behavior: A dyadic exploration of the influence of salesperson emotional intelligence on customer participation and citizenship behavior. J. Bus. Res. 2018, 92, 9-24. [CrossRef]

53. Groth, M. Customers as good soldiers: Examining citizenship behaviors in internet service deliveries. J. Manag. 2005, 31, 7-27. [CrossRef]

54. Bettencourt, L.A. Customer voluntary performance: Customers as partners in service delivery. J. Retail. 1997, 73, 383-406. [CrossRef]

55. Chen, C.; Du, R.; Li, J.; Fan, W. The impacts of knowledge sharing-based value co-creation on user continuance in online communities. Inf. Discov. Deliv. 2017, 45, 227-239. [CrossRef]

56. Chen, W.-J. The model of service-oriented organizational citizenship behavior among international tourist hotels. J. Hosp. Tour. Manag. 2016, 29, 24-32. [CrossRef]

57. Neuhofer, B.; Buhalis, D.; Ladkin, A. Smart technologies for personalized experiences: A case study in the hospitality domain. Electron. Mark. 2015, 25, 243-254. [CrossRef]

58. Blau, P.M. Exchange and Power in Social Life; John Wiley: New York, NY, USA, 1964; p. 372.

59. Lee, M.K.; Cheung, C.M.; Lim, K.H.; Sia, C.L. Understanding customer knowledge sharing in web-based discussion boards: An exploratory study. Internet Res. 2006, 16, 289-303. [CrossRef]

60. Koenig, M.; Srikantaiah, T. The evaluation of knowledge management. In Knowledge Management for the Information Professional; ASIS Monograph Series; Medford, N.J., Ed.; The American Society for Information Science by Information Today: Medford, NJ, USA, 2000; pp. 23-36.

61. Butler, Y. Knowledge management-If only you knew what you knew. Aust. Libr. J. 2000, 49, 31-43. [CrossRef] 
62. Füller, J.; Bilgram, V. The moderating effect of personal features on the consequences of an enjoyable co-creation experience. J. Prod. Brand Manag. 2017, 26, 386-401. [CrossRef]

63. Algharabat, R.S. The role of telepresence and user engagement in co-creation value and purchase intention: Online retail context. J. Internet Commer. 2018, 17, 1-25. [CrossRef]

64. Elsharnouby, T.H.; Mahrous, A.A. Customer participation in online co-creation experience: The role of e-service quality. J. Res. Interact. Mark. 2015, 9, 313-336. [CrossRef]

65. Choi, E.; Ko, E.; Kim, A.J. Explaining and predicting purchase intentions following luxury-fashion brand value co-creation encounters. J. Bus. Res. 2016, 69, 5827-5832. [CrossRef]

66. Guzel, M.; Sezen, B.; Alniacik, U. Drivers and consequences of customer participation into value co-creation: A field experiment. J. Prod. Brand Manag. 2020. ahead-of-print. [CrossRef]

67. Lee, Y.; Kim, I. A value co-creation model in brand tribes: The effect of luxury cruise consumers' power perception. Serv. Bus. 2019, 13, 129-152. [CrossRef]

68. Gyenge, B.; Máté, Z.; Vida, I.; Bilan, Y.; Vasa, L. A New Strategic Marketing Management Model for the Specificities of E-Commerce in the Supply Chain. J. Theor. Appl. Electron. Commer. Res. 2021, 16, 1136-1149. [CrossRef]

69. Dang, V.T.; Nguyen, N.; Pervan, S. Retailer corporate social responsibility and consumer citizenship behavior: The mediating roles of perceived consumer effectiveness and consumer trust. J. Retail. Consum. Serv. 2020, 55, 102082. [CrossRef]

70. Moghadamzadeh, A.; Ebrahimi, P.; Radfard, S.; Salamzadeh, A.; Khajeheian, D. Investigating the role of customer co-creation behavior on social media platforms in rendering innovative services. Sustainability 2020, 12, 6926. [CrossRef]

71. Yi, Y.; Nataraajan, R.; Gong, T. Customer participation and citizenship behavioral influences on employee performance, satisfaction, commitment, and turnover intention. J. Bus. Res. 2011, 64, 87-95. [CrossRef]

72. Fowler, J.G. Customer citizenship behavior: An expanded theoretical understanding. Int. J. Bus. Soc. Sci. 2013, 4, 101-109.

73. Matzler, K.; Pichler, E.; Füller, J.; Mooradian, T.A. Personality, person-brand fit, and brand community: An investigation of individuals, brands, and brand communities. J. Mark. Manag. 2011, 27, 874-890. [CrossRef]

74. Ridings, C.M.; Gefen, D.; Arinze, B. Some antecedents and effects of trust in virtual communities. J. Strateg. Inf. Syst. 2002, 11, 271-295. [CrossRef]

75. Chiu, C.-M.; Huang, H.-Y.; Yen, C.-H. Antecedents of trust in online auctions. Electron. Commer. Res. Appl. 2010, 9, 148-159. [CrossRef]

76. Chan, K.W.; Gong, T.; Zhang, R.; Zhou, M. Do employee citizenship behaviors lead to customer citizenship behaviors? The roles of dual identification and service climate. J. Serv. Res. 2017, 20, 259-274. [CrossRef]

77. Tung, V.W.S.; Chen, P.-J.; Schuckert, M. Managing customer citizenship behaviour: The moderating roles of employee responsiveness and organizational reassurance. Tour. Manag. 2017, 59, 23-35. [CrossRef]

78. Ngo, L.V.; O'cass, A. Innovation and business success: The mediating role of customer participation. J. Bus. Res. 2013, 66, 1134-1142. [CrossRef]

79. Hwang, J.; Kim, H. Consequences of a green image of drone food delivery services: The moderating role of gender and age. Bus. Strategy Environ. 2019, 28, 872-884. [CrossRef]

80. Chang, $\mathrm{C}$. The influence of masculinity and femininity in different advertising processing contexts: An accessibility perspective. Sex Roles 2006, 55, 345-356. [CrossRef]

81. Gould, S.J.; Weil, C.E. Gift-giving roles and gender self-concepts. Sex Roles 1991, 24, 617-637. [CrossRef]

82. Shin, Y.H.; Jung, S.E.; Im, J.; Severt, K. Applying an extended theory of planned behavior to examine state-branded food product purchase behavior: The moderating effect of gender. J. Foodserv. Bus. Res. 2020, 23, 358-375. [CrossRef]

83. Radojka, K.; Filipović, Z. Gender differences and consumer behavior of millennials. Acta Econ. Et Tur. 2017, 3, 5-13.

84. Lin, X.; Featherman, M.; Brooks, S.L.; Hajli, N. Exploring gender differences in online consumer purchase decision making: An online product presentation perspective. Inf. Syst. Front. 2019, 21, 1187-1201. [CrossRef]

85. Ma, E.; Qu, H.; Eliwa, R.A. Customer loyalty with fine dining: The moderating role of gender. J. Hosp. Mark. Manag. 2014, 23, 513-535. [CrossRef]

86. Hwang, Y. The moderating effects of gender on e-commerce systems adoption factors: An empirical investigation. Comput. Hum. Behav. 2010, 26, 1753-1760. [CrossRef]

87. Hsu, M.-H.; Ju, T.L.; Yen, C.-H.; Chang, C.-M. Knowledge sharing behavior in virtual communities: The relationship between trust, self-efficacy, and outcome expectations. Int. J. Hum.-Comput. Stud. 2007, 65, 153-169. [CrossRef]

88. Hair, J.F., Jr.; Sarstedt, M.; Matthews, L.M.; Ringle, C.M. Identifying and treating unobserved heterogeneity with FIMIX-PLS: Part I-method. Eur. Bus. Rev. 2016, 28, 63-76. [CrossRef]

89. Hair, J.F.; Risher, J.J.; Sarstedt, M.; Ringle, C.M. When to use and how to report the results of PLS-SEM. Eur. Bus. Rev. 2019, 31, 2-24. [CrossRef]

90. Ringle, C.M.; Wende, S.; Becker, J.-M. SmartPLS 3. Bönningstedt: SmartPLS. Available online: http://www.smartpls.com. (accessed on 23 April 2021).

91. Sarstedt, M.; Ringle, C.M.; Hair, J.F. Partial least squares structural equation modeling. In Handbook of Market Research; Springer: Berlin/Heidelberg, Germany, 2017; pp. 1-40.

92. Hair, J.F., Jr.; Hult, G.T.M.; Ringle, C.M.; Sarstedt, M. A Primer on Partial Least Squares Structural Equation Modeling (PLS-SEM), 2nd ed.; Sage Publications: Thousand Oaks, CA, USA, 2017. 
93. Gholampour, A.; Jamshidi, M.H.M.; Habibi, A.; Motamedi Dehkordi, N.; Ebrahimi, P. The Impact of Hospital Information System on Nurses' Satisfaction in Iranian Public Hospitals: The Moderating Role of Computer Literacy. J. Inf. Technol. Manag. 2020, 12, 141-159.

94. Ebrahimi, P.; Ahmadi, M.; Gholampour, A.; Alipour, H. CRM performance and development of media entrepreneurship in digital, social media and mobile commerce. Int. J. Emerg. Mark. 2019, 16, 25-50. [CrossRef]

95. Janavi, E.; Soleimani, M.; Gholampour, A.; Friedrichsen, M.; Ebrahimi, P. Effect of Social Media Adoption and Media Needs on Online Purchase Behavior: The Moderator Roles of Media Type, Gender, Age. J. Inf. Technol. Manag. 2021, 13, 1-24.

96. Ebrahimi, P.; Hajmohammadi, A.; Khajeheian, D. Place branding and moderating role of social media. Curr. Issues Tour. 2020, 23, 1723-1731. [CrossRef]

97. Khajeheian, D.; Ebrahimi, P. Media branding and value co-creation: Effect of user participation in social media of newsmedia on attitudinal and behavioural loyalty. Eur. J. Int. Manag. 2020, 14, 254-273. [CrossRef]

98. Shmueli, G.; Sarstedt, M.; Hair, J.F.; Cheah, J.-H.; Ting, H.; Vaithilingam, S.; Ringle, C.M. Predictive model assessment in PLS-SEM: Guidelines for using PLSpredict. Eur. J. Mark. 2019, 53, 2322-2347. [CrossRef]

99. Sanchez, G. PLS Path Modeling with R; Trowchez Editions: Berkeley, CA, USA, 2013.

100. Chaouali, W.; Souiden, N.; Ringle, C.M. Elderly customers' reactions to service failures: The role of future time perspective, wisdom and emotional intelligence. J. Serv. Mark. 2020, 35, 65-77. [CrossRef]

101. Henseler, J.; Ringle, C.M.; Sarstedt, M. A new criterion for assessing discriminant validity in variance-based structural equation modeling. J. Acad. Mark. Sci. 2015, 43, 115-135. [CrossRef]

102. Sarkar, A.; Qian, L.; Peau, A.K. Structural equation modeling for three aspects of green business practices: A case study of Bangladeshi RMG's industry. Environ. Sci. Pollut. Res. 2020, 27, 35750-35768. [CrossRef] [PubMed]

103. Ringle, C.M.; Sarstedt, M. Gain more insight from your PLS-SEM results: The importance-performance map analysis. Ind. Manag. Data Syst. 2016, 116, 1865-1886. [CrossRef]

104. Matthews, L.M.; Sarstedt, M.; Hair, J.F.; Ringle, C.M. Identifying and treating unobserved heterogeneity with FIMIX-PLS: Part II-A case study. Eur. Bus. Rev. 2016, 28, 208-224. [CrossRef]

105. Hair, J.F., Jr.; Ringle, C.; Sarstedt, M.; Gudergan, S.P. Advanced Issues in Partial Least Square Structural Equation Modeling; Sage Publications Ltd.: Thousand Oaks, CA, USA, 2018.

106. Shmueli, G.; Ray, S.; Estrada, J.M.V.; Chatla, S.B. The elephant in the room: Predictive performance of PLS models. J. Bus. Res. 2016, 69, 4552-4564. [CrossRef]

107. Sanchez-Franco, M.J.; Ramos, A.F.V.; Velicia, F.A.M. The moderating effect of gender on relationship quality and loyalty toward Internet service providers. Inf. Manag. 2009, 46, 196-202. [CrossRef]

108. Mitchell, V.W.; Walsh, G. Gender differences in German consumer decision-making styles. J. Consum. Behav. Int. Res. Rev. 2004, 3, 331-346. [CrossRef] 